\title{
Drug sensitivity of Proteus species
}

\author{
C. T. HUANG AND GRACE CHOU \\ From the Department of Pathology and Bacteriology, University of Hong Kong
}

SYNOPSIS The results of sensitivity test for four Proteus species were compared. $P$. mirabilis was, in general, more drug sensitive than the other species and $P$. rettgeri was the least sensitive. The conclusion was drawn that species identification of Proteus is essential in routine bacteriological diagnosis.

The genus Proteus is frequently encountered in urinary tract infection and is not uncommonly a secondary invader of wounds. It is comparatively more resistant to antibacterial agents generally employed than many Gram-negative rods and is, therefore, one of the most difficult organisms to tackle clinically. With the introduction of ampicillin and nalidixic acid into the armoury of antibacterial agents, it was found that these drugs were satisfactory in the control of Proteus infection which did not yield to other agents (Stratford, 1964; Barlow, 1963; Ward-McQuaid, Jichlinski, and Macis, 1963). Marked differences in drug susceptibility were demonstrated among species of Proteus (Potee, Wright, and Finland, 1954; Barber and Waterworth, 1964). Unfortunately, in routine bacteriological diagnosis, the differentiation of Proteus into its species is often not practised because further tests require more materials, time, and labour. In a previous paper, one of the authors (Huang, 1966) described a set of two-tube Multitest media which enabled rapid differentiation of this genus into its four accepted species, namely, $P$. mirabilis, $P$. morganii, $P$. vulgaris, and $P$. rettgeri. This report compares the results of disk sensitivity tests of the four species to 10 antibacterial agents in two different solid media and to illustrate how widely drug sensitivity varies with the species.

\section{MATERIALS AND METHODS}

The Proteus strains described were isolated mainly from urine and pus or aspirates and many strains obtained from stools were also included for comparison. These strains were isolated from patients of different wards in a general hospital (the Queen Mary Hospital of Hong Kong) which has more than 600 beds. The strains were collected between January 1965 and December 1966. The methods of isolation, screening for urease activity, and identification of species were the same as previously

Received for publication 8 June 1967. reported (Huang, 1966). The inoculum for the test was obtained by suspending a heavy loopful of the growth which showed positive urease reaction in the slope of the modified Kohn's medium 1 into $2 \mathrm{ml}$. of $1 \%$ peptone water. A cotton swab was soaked in the suspension, drained and evenly spread over the surface of the agar plate. Oxoid S.T. agar (CM 215) and ordinary infusion agar plates were employed in duplicate for comparison. Oxoid S.T. agar was used because it is sulphonamideinhibitor free, the salt concentration has been reduced from $0.5 \%$ to $0.3 \%$ and is buffered. The reduction of salt concentration allows of no interference with the activities of streptomycin and ampicillin (Barber and Waterworth, 1964) and at the same time the swarming of Proteus is prevented (Sandys, 1960); thus the spreading edge of the growth of Proteus which might lead to error in reading the inhibitory zone (Report, 1965) is obviated. Oxoid Multodisks containing nitrofurantoin, chloramphenicol, streptomycin, tetracycline, sulphafurazole, and polymyxin B were used. In addition, disks containing kanamycin and neomycin prepared in this laboratory, and ampicillin and nalidixic acid supplied respectively by the Beecham Laboratories Overseas Ltd. (England) and the Winthrop Product Inc. (U.S.A.) were included. The amount of the drugs per disk are indicated in Tables I and II. These were in accordance with estimates which would indicate effectiveness of the drugs in vivo at the usual blood levels. For ampicillin and nalidixic acid, three concentrations of each drug were, however, tested. The cultures for the sensitivity test were incubated at $37^{\circ} \mathrm{C}$. and reading for the presence or absence of zones of inhibition of growth was made 16 to 20 hours afterwards.

\section{RESULTS AND COMMENT}

Tables I and II present the results of in vitro sensitivity tests of the four Proteus species in Oxoid S.T. agar and infusion agar media respectively. Figure 1 demonstrates the relative sensitiveness of the species tested in Oxoid S.T. agar medium. As is shown in Fig. 1, over $90 \%$ of each species were sensitive to nalidixic acid and over $80 \%$ of each were sensitive to kanamycin and neomycin. On the 
TABLE I

RESULT OF SENSITIVITY TEST IN OXOID $S$. T. AGAR

\begin{tabular}{|c|c|c|c|c|c|c|c|c|c|c|c|c|c|c|c|}
\hline \multirow[t]{2}{*}{ Organism } & \multirow{2}{*}{$\begin{array}{l}\text { No. of } \\
\text { Strains } \\
\text { Tested }\end{array}$} & \multicolumn{14}{|c|}{ No. of Strains Sensitive to } \\
\hline & & $\begin{array}{l}F \\
(50 \mu g)\end{array}$ & $\begin{array}{l}C \\
(10 \mu g)\end{array}$ & $\begin{array}{l}S \\
(10 \mu g)\end{array}$ & $\begin{array}{l}T \\
(10 \mu g)\end{array}$ & $\begin{array}{l}G \\
(100 \mu g)\end{array}$ & $\begin{array}{l}P B \\
\text { (100ut.) }\end{array}$ & $\begin{array}{l}K \\
(10 \mu g)\end{array}$ & $\begin{array}{l}N \\
(10 \mu g)\end{array}$ & $\begin{array}{l}A \\
(10 \mu g)\end{array}$ & $\begin{array}{l}A \\
(25 \mu g)\end{array}$ & $\begin{array}{l}A \\
(50 \mu g)\end{array}$ & $\begin{array}{l}N A \\
(5 \mu g)\end{array}$ & $\begin{array}{l}N A \\
(30 \mu g)\end{array}$ & $\begin{array}{l}N A \\
(60 \mu g)\end{array}$ \\
\hline P. mirabilis & 350 & $\begin{array}{l}280 \\
(80 \cdot 0)^{1}\end{array}$ & $\begin{array}{l}306 \\
(87 \cdot 4)\end{array}$ & $\begin{array}{l}239 \\
(68 \cdot 2)\end{array}$ & $\begin{array}{l}4 \\
(1 \cdot 1)\end{array}$ & $\begin{array}{l}50 \\
(14 \cdot 2)\end{array}$ & $\begin{array}{l}5 \\
(1 \cdot 4)\end{array}$ & $\begin{array}{l}319 \\
(91 \cdot 1)\end{array}$ & $\begin{array}{l}328 \\
(93 \cdot 7)\end{array}$ & $\begin{array}{l}320 \\
(91 \cdot 5)\end{array}$ & $\begin{array}{l}338 \\
(96 \cdot 5)\end{array}$ & $\begin{array}{l}348 \\
(97 \cdot 1)\end{array}$ & $\begin{array}{l}330 \\
(94 \cdot 8)\end{array}$ & $\begin{array}{l}350 \\
(100)\end{array}$ & $\begin{array}{l}350 \\
(100)\end{array}$ \\
\hline P. morganii & 60 & $\begin{array}{c}53 \\
(88 \cdot 3)\end{array}$ & $\begin{array}{c}34 \\
(56.6)\end{array}$ & $\begin{array}{c}26 \\
(43 \cdot 3)\end{array}$ & $\begin{array}{c}13 \\
(21 \cdot 3)\end{array}$ & $\begin{array}{c}10 \\
(16 \cdot 6)\end{array}$ & $\begin{array}{l}4 \\
(6 \cdot 6)\end{array}$ & $\begin{array}{c}57 \\
(95.0)\end{array}$ & $\begin{array}{c}58 \\
(96.6)\end{array}$ & $\begin{array}{c}2 \\
(3 \cdot 3)\end{array}$ & $\begin{array}{c}19 \\
(31 \cdot 6)\end{array}$ & $\begin{array}{c}35 \\
(58 \cdot 3)\end{array}$ & $\begin{array}{c}55 \\
(91 \cdot 6)\end{array}$ & $\begin{array}{c}60 \\
(100)\end{array}$ & $\begin{array}{c}60 \\
(100)\end{array}$ \\
\hline P. vulgaris & 60 & $\begin{array}{c}41 \\
(68 \cdot 3)\end{array}$ & $\begin{array}{c}34 \\
(56 \cdot 6)\end{array}$ & $\begin{array}{c}32 \\
(53 \cdot 3)\end{array}$ & $\begin{array}{l}14 \\
(23 \cdot 3)\end{array}$ & $\begin{array}{c}7 \\
(11 \cdot 6)\end{array}$ & $\begin{array}{l}3 \\
(5.0)\end{array}$ & $\begin{array}{c}58 \\
(96.6)\end{array}$ & $\begin{array}{c}58 \\
(96.6)\end{array}$ & $\begin{array}{c}4 \\
(6 \cdot 6)\end{array}$ & $\begin{array}{c}14 \\
(23 \cdot 3)\end{array}$ & $\begin{array}{c}24 \\
(40 \cdot 0)\end{array}$ & $\begin{array}{c}50 \\
(83 \cdot 3)\end{array}$ & $\begin{array}{c}56 \\
(93.3)\end{array}$ & $\begin{array}{l}60 \\
(100)\end{array}$ \\
\hline P. rettgeri & 80 & $\begin{array}{c}6 \\
(7 \cdot 5)\end{array}$ & $\begin{array}{c}7 \\
(8 \cdot 7)\end{array}$ & $\begin{array}{c}4 \\
(5 \cdot 0)\end{array}$ & $\begin{array}{c}2 \\
(2 \cdot 5)\end{array}$ & $\begin{array}{l}5 \\
(6 \cdot 25)\end{array}$ & $\begin{array}{l}0 \\
(0)\end{array}$ & $\begin{array}{c}68 \\
(85 \cdot 0)\end{array}$ & $\begin{array}{c}67 \\
(83 \cdot 7)\end{array}$ & $\begin{array}{c}18 \\
(22 \cdot 5)\end{array}$ & $\begin{array}{c}40 \\
(50.0)\end{array}$ & $\begin{array}{c}62 \\
(77 \cdot 5)\end{array}$ & $\begin{array}{c}69 \\
(86.2)\end{array}$ & $\begin{array}{c}74 \\
(92 \cdot 5)\end{array}$ & $\begin{array}{c}77 \\
(96 \cdot 2\end{array}$ \\
\hline
\end{tabular}

${ }^{1}$ Figures in brackets represent percentage of sensitive strain.

$F=$ nitrofurantoin; $C=$ chloramphenicol; $S=$ streptomycin; $T=$ tetracycline; $G=$ sulphafurazole;

$P B=$ polymyxin $\mathrm{B} ; K=$ kanamycin $N=$ neomycin; $A=$ ampicillin; $N A=$ nalidixic acid

TABLE II

RESULT OF SENSITIVITY TEST IN INFUSION AGAR

\begin{tabular}{|c|c|c|c|c|c|c|c|c|c|c|c|c|c|c|c|}
\hline \multirow[t]{2}{*}{ Organism } & \multirow{2}{*}{$\begin{array}{l}\text { No. of } \\
\text { Strains } \\
\text { Tested }\end{array}$} & \multicolumn{14}{|c|}{ No. of Sensitive Strains } \\
\hline & & $\begin{array}{l}F \\
(50 \mu g)\end{array}$ & $\begin{array}{l}C \\
(10 \mu g)\end{array}$ & $\underset{(10 \mu g)}{S}$ & $\begin{array}{l}T \\
(10 \mu g)\end{array}$ & $\underset{(100 \mu g)}{G}$ & $\begin{array}{l}P B \\
(100 u t .)\end{array}$ & $\begin{array}{l}K \\
(10 \mu g)\end{array}$ & $\begin{array}{l}N \\
(10 \mu g)\end{array}$ & $\underset{(10 \mu g)}{A}$ & $\underset{(25 \mu g)}{A}$ & $\underset{(50 \mu g)}{A}$ & $\begin{array}{c}N A \\
(5 \mu g)\end{array}$ & $\begin{array}{c}N A \\
(30 \mu g)\end{array}$ & $\begin{array}{l}N A \\
(60 \mu g)\end{array}$ \\
\hline P. mirabilis & 350 & $\begin{array}{l}96 \\
(35 \cdot 5)\end{array}$ & $\begin{array}{l}216 \\
(61 \cdot 6)\end{array}$ & $\begin{array}{l}202 \\
(57 \cdot 7)\end{array}$ & $\begin{array}{l}12 \\
(3 \cdot 7)\end{array}$ & $\begin{array}{l}6 \\
(1 \cdot 8)\end{array}$ & $\begin{array}{l}3 \\
(0.9)\end{array}$ & $\begin{array}{l}293 \\
(83 \cdot 8)\end{array}$ & $\begin{array}{l}234 \\
(92 \cdot 1)\end{array}$ & $\begin{array}{l}322 \\
(91 \cdot 8)\end{array}$ & $\begin{array}{l}349 \\
(98 \cdot 3)\end{array}$ & $\begin{array}{l}349 \\
(98 \cdot 3)\end{array}$ & $\begin{array}{l}171 \\
(49 \cdot 0)\end{array}$ & $\begin{array}{l}333 \\
(95 \cdot 4)\end{array}$ & $\begin{array}{l}350 \\
(100)\end{array}$ \\
\hline P. morganii & 60 & $\begin{array}{l}40 \\
(66 \cdot 6)\end{array}$ & $\begin{array}{l}21 \\
(35 \cdot 0)\end{array}$ & $\begin{array}{l}23 \\
(38 \cdot 3)\end{array}$ & $\begin{array}{c}13 \\
(21 \cdot 6)\end{array}$ & $\begin{array}{l}2 \\
(3 \cdot 3)\end{array}$ & $\begin{array}{l}5 \\
(8 \cdot 3)\end{array}$ & $\begin{array}{l}55 \\
(91 \cdot 6)\end{array}$ & $\begin{array}{c}56 \\
(94 \cdot 8)\end{array}$ & $\begin{array}{c}3 \\
(5 \cdot 0)\end{array}$ & $\begin{array}{c}9 \\
(15.0)\end{array}$ & $\begin{array}{l}28 \\
(46.6)\end{array}$ & $\begin{array}{c}57 \\
(95.0)\end{array}$ & $\begin{array}{c}59 \\
(98 \cdot 3)\end{array}$ & $\begin{array}{c}60 \\
(100)\end{array}$ \\
\hline P. vulgaris & 60 & $\begin{array}{l}20 \\
(28 \cdot 8)\end{array}$ & $\begin{array}{l}25 \\
(42 \cdot 3)\end{array}$ & $\begin{array}{c}27 \\
(45 \cdot 7)\end{array}$ & $\begin{array}{l}15 \\
(26 \cdot 9)\end{array}$ & $\begin{array}{l}3 \\
(3 \cdot 8)\end{array}$ & $\begin{array}{l}1 \\
(1.9)\end{array}$ & $\begin{array}{l}54 \\
(93 \cdot 8)\end{array}$ & $\begin{array}{c}54 \\
(93.8)\end{array}$ & $\begin{array}{c}5 \\
(8 \cdot 2)\end{array}$ & $\begin{array}{c}6 \\
(10 \cdot 0)\end{array}$ & $\begin{array}{c}7 \\
(11 \cdot 6)\end{array}$ & $\begin{array}{c}51 \\
(86 \cdot 0)\end{array}$ & $\begin{array}{c}57 \\
(95 \cdot 0)\end{array}$ & $\begin{array}{l}58 \\
(96 \cdot 6)\end{array}$ \\
\hline P. rettgeri & 80 & $\begin{array}{l}2 \\
(2 \cdot 5)\end{array}$ & $\begin{array}{c}3 \\
(3 \cdot 7)\end{array}$ & $\begin{array}{c}2 \\
(2 \cdot 5)\end{array}$ & $\begin{array}{l}1 \\
(1 \cdot 3)\end{array}$ & $\begin{array}{l}0 \\
(0)\end{array}$ & $\begin{array}{l}1 \\
(1 \cdot 3)\end{array}$ & $\begin{array}{c}55 \\
(68 \cdot 5)\end{array}$ & $\begin{array}{c}56 \\
(70 \cdot 0)\end{array}$ & $\begin{array}{c}9 \\
(11 \cdot 2)\end{array}$ & $\begin{array}{c}13 \\
(16 \cdot 2)\end{array}$ & $\begin{array}{c}22 \\
(27 \cdot 5)\end{array}$ & $\begin{array}{c}68 \\
(85 \cdot 0)\end{array}$ & $\begin{array}{c}74 \\
(92 \cdot 5)\end{array}$ & $\begin{array}{l}77 \\
(96 \cdot 2)\end{array}$ \\
\hline
\end{tabular}

${ }^{1}$ Figures in brackets represent percentages of sensitive strains.

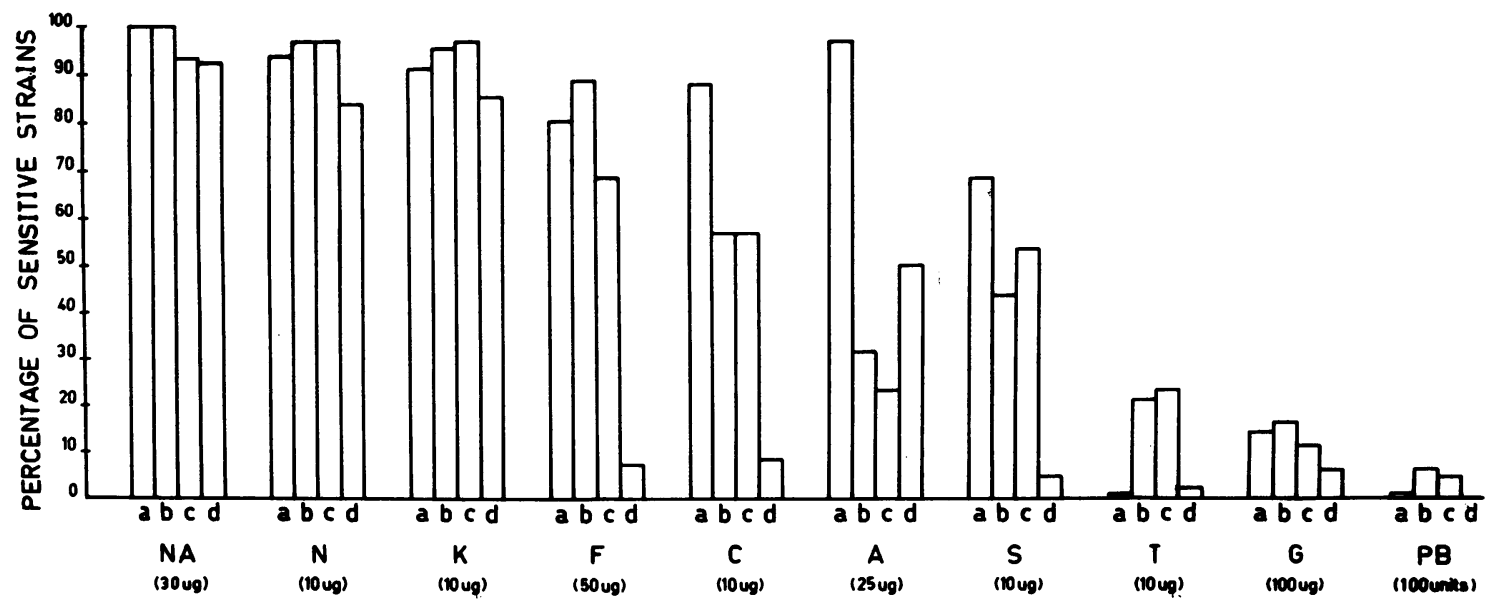

FIG.1. Drug sensitivity of Proteus species. $\mathrm{a}=P$. mirabilis; $\mathrm{b}=P$. morganii; $\mathrm{c}=P$. vulgaris and $\mathrm{d}=P$. rettgeri. 
whole, $\boldsymbol{P}$. mirabilis was sensitive to more antibacterial agents than the other species and $P$. rettgeri was the least sensitive. According to Carroll (1963) nalidixic acid was non-nephrotoxic, readily absorbed from the gut and rapidly excreted in therapeutic concentrations by the kidney. It appears that this is the drug of choice in the control of urinary tract infection with Proteus because of its wider range of activity against all four species.

The results confirmed that $\boldsymbol{P}$. mirabilis was the most sensitive species to penicillin or its derivatives (Potee et al., 1954; Barber and Waterworth, 1964). In this series, more than $90 \%$ of the strains of $P$. mirabilis were sensitive to ampicillin at a concentration of $10 \mu \mathrm{g}$ per disk. The fact that Proteus strains were in general insensitive to polymyxin B and only occasionally sensitive to tetracycline (Giles and Suttleworth, 1958; Tolhurst and Williams, 1963) was also verified. Though Tolhurst and Williams found that $65 \%$ of their strains were sensitive to sulphadiazine, our results showed that sulphafurazole has practically little inhibitory effect against Proteus even when the sensitivity tests were performed in the sulphonamide-inhibitor free Oxoid S.T. agar medium. The ineffectiveness might be in part due to the development of sulphonamide resistant strains in recent years or because of a heavier inoculum employed in our experiments. It has been found that even flooding a plate with a culture suspension would give rise to error in the sulphonamide sensitivity test (Report, 1965). Giles and Suttleworth (1958) also found that the frequency of resistant strains of Proteus to streptomycin rose from $28 \%$ to $43 \%$ and to chloramphenicol from $27 \%$ to $37 \%$ during the years 1951 to 1956 . We have no previous data to compare the decline of sensitivity of Proteus to these two antibiotics. But, with the exception of $P$. rettgeri, a considerable number of our strains were sensitive to streptomycin and chloramphenicol.

More sensitive strains to sulphafurazole, streptomycin, ampicillin, and nitrofurantoin were ob- served in Oxoid S.T. agar than in infusion agar medium. This is obvious, because Oxoid S.T. agar is sulphonamide-inhibitor free, and has a lower salt concentration. The marked difference in results with nitrofurantoin sensitivity is attributed to the presence of $1 \%$ glucose in the Oxoid S.T. agar medium. This finding confirmed the observation of Fullerton (Report, 1965). This is illustrated by the experiment presented in Table III in which five strains of $P$. mirabilis (strains 94611, 96315, 96466, 97587, and 100215) that had shown discrepancy in the two media previously were re-tested in media with or without glucose. Strains which were sensitive (90638 and 100208) or resistant (92448 and 95131) to nitrofurantoin in both media were included for controls. As is shown, discrepancy occurred when Oxoid D.S.T. agar (CM 261), which has exactly the same composition as Oxoid S.T. agar (CM 215) except the glucose content was reduced from $1 \%$ to $0.2 \%$, was used. The effect of glucose on the activity of nitrofurantoin is still obscure. Nevertheless for the nitrofurantoin sensitivity test a medium containing a sugar utilizable by an organism should not be employed, because it may lead to a falsely sensitive result.

No difference was observed in sensitivities among strains of Proteus isolated from various types of clinical specimens. But strains showing multiple resistance to many drugs were observed and these were more often found with $P$. rettgeri strains (Table IV). Two strains of this species isolated from urine were insensitive to all 10 drugs at the concentrations employed, including nalidixic acid at $60 \mu \mathrm{g}$ per disk and ampicillin at $50 \mu \mathrm{g}$ per disk. Barlow (1963) reported rapidly increasing resistance to nalidixic acid by strains of Escherichia coli and suggested that the development of drug-resistant strains might become a problem if nalidixic acid were widely used.

Considering the results indicated in Table $I$, it is clear that species identification of Proteus is essential. For example, if the species were not differen-

TABLE III

NITROFURANTOIN SENSITIVITY OF $P$. MIRABILIS IN MEDIA WITH OR WITHOUT GLUCOSE

\begin{tabular}{|c|c|c|c|c|c|c|c|c|c|}
\hline \multirow[t]{2}{*}{ Medium } & \multicolumn{9}{|c|}{ Strain Number } \\
\hline & 94611 & 96315 & 96466 & 97587 & 100215 & 90638 & 100208 & 92448 & 95131 \\
\hline Infusion agar & $\mathbf{R}$ & $\mathbf{R}$ & $\mathbf{R}$ & $\mathbf{R}$ & $\mathbf{R}$ & $\mathbf{S}$ & $\mathbf{S}$ & $\mathbf{R}$ & $\mathbf{R}$ \\
\hline $\begin{array}{c}\text { Infusion agar } \div \\
1 \% \text { lactose }\end{array}$ & $\mathbf{R}$ & $\mathbf{R}$ & $\mathbf{R}$ & $\mathbf{R}$ & $\mathbf{R}$ & $\mathbf{S}$ & $\mathbf{S}$ & $\vec{R}$ & $\mathbf{R}$ \\
\hline $\begin{array}{c}\text { Infusion agar }+ \\
1 \% \text { dextrose }\end{array}$ & $\mathbf{S}$ & $\mathbf{S}$ & $\mathbf{S}$ & $\mathbf{S}$ & $\mathbf{S}$ & $\mathbf{S}$ & $\mathbf{S}$ & $\mathbf{R}$ & $\mathbf{R}$ \\
\hline $\begin{array}{l}\text { Oxoid S.T. agar } \\
(1 \% \text { dextrose })\end{array}$ & $\mathbf{S}$ & $\mathbf{S}$ & $\mathbf{S}$ & $\mathbf{S}$ & $\mathbf{S}$ & $\mathbf{S}$ & $\mathbf{S}$ & $\mathbf{R}$ & $\mathbf{R}$ \\
\hline $\begin{array}{c}\text { Oxoid D.S.T. agar } \\
(0.2 \% \text { dextrose })\end{array}$ & $\mathbf{S}$ & $\mathbf{R}$ & $\mathbf{R}$ & $\mathbf{S}$ & $\mathbf{R}$ & $\mathbf{S}$ & $\mathbf{S}$ & $\mathbf{R}$ & $\mathbf{R}$ \\
\hline
\end{tabular}


TABLE IV

EXTENT OF MULTIPLE DRUG RESISTANCE OF PROTEUS SPECIES

\begin{tabular}{|c|c|c|c|c|c|c|c|c|c|c|c|}
\hline \multirow[t]{2}{*}{ Organism } & \multirow{2}{*}{$\begin{array}{l}\text { Total No. } \\
\text { of Strains } \\
\text { Tested }\end{array}$} & \multicolumn{10}{|c|}{ Number of Drugs } \\
\hline & & 1 & 2 & 3 & 4 & 5 & 6 & 7 & 8 & 9 & 10 \\
\hline $\begin{array}{l}\text { P. mirabilis } \\
\text { P. morganii } \\
\text { P. vulgaris } \\
\text { P. rettgeri }\end{array}$ & $\begin{array}{r}350 \\
60 \\
60 \\
80\end{array}$ & $\begin{array}{l}3^{1} \\
1 \\
2 \\
0\end{array}$ & $\begin{array}{r}31 \\
10 \\
0 \\
0\end{array}$ & $\begin{array}{r}161 \\
6 \\
4 \\
1\end{array}$ & $\begin{array}{r}92 \\
9 \\
19 \\
7\end{array}$ & $\begin{array}{r}40 \\
18 \\
18 \\
8\end{array}$ & $\begin{array}{l}15 \\
12 \\
11 \\
19\end{array}$ & $\begin{array}{r}6 \\
2 \\
3 \\
31\end{array}$ & $\begin{array}{l}2 \\
2 \\
0 \\
6\end{array}$ & $\begin{array}{l}0 \\
0 \\
3 \\
6\end{array}$ & $\begin{array}{l}\mathbf{0} \\
\mathbf{0} \\
\mathbf{0} \\
\mathbf{2}\end{array}$ \\
\hline
\end{tabular}

${ }^{1}$ Figures indicate numbers of resistant strains.

tiated in this series, the overall percentage of sensitive strains of Proteus to ampicillin $(25 \mu \mathrm{g})$ would be $61.4 \%$ and to chloramphenicol $(10 \mu \mathrm{g})$ would be $69.2 \%$. Such data are erroneous because the actual percentage of sensitive strains of $\boldsymbol{P}$. mirabilis to ampicillin was much higher $(96.5 \%)$ and, on the other hand, the actual percentage of sensitive strains of $P$. rettgeri to chloramphenicol was very low (8.7\%). The Multitest media (Huang, 1966), which enables rapid differentiation of species without excessive use of materials and labour, are therefore, very helpful in routine sensitivity testing of Proteus.

\section{REFERENCES}

Barber, M., and Waterworth, P. M. (1964). J. clin. Path., 17, 69. Barlow, A. M. (1963). Brit. med. J., 2, 1308.

Carroll, G. (1963). J. Urol. (Baltimore), 90, 476.

Giles, C., and Suttleworth, E. M. (1958). J. clin. Path., 11, 185.

Huang, C. T. (1966). Ibid., 19, 438.

Potee, K. G., Wright, S. S., and Finland, M. (1954). J. lab. clin. Med., 44, 463.

Report on antibiotic sensitivity test trial (1965). J. clin. Path., 18, 1.

Sandys, G. H. (1960). J. med. Lab. Technol., 17, 224.

Stratford, B. C. (1964). Postgrad. med. J. (suppl.), 40, 68.

Tolhurst, J. C., Buckle, G., and Williams, S. W. (1963). Chem otherapy with Antibiotics and Allied Drugs, 2nd ed. Special Report Series No. 6. N.H.M.R.C., Canberra.

Ward-McQuaid, J. F. N. C., Jichlinski, D., and Macis, R. (1963). Brit. med. J., 2, 1311.

\section{Reports and Bulletins prepared by the Association of Clinical Biochemists}

The following reports and bulletins are published by the Association of Clinical Biochemists. They may be obtained from Mr. J. T. Ireland, Biochemistry Laboratory, Alder Hey Children's Hospital, Liverpool, 12. The prices include postage, but airmail will be charged extra.

\section{SCIENTIFIC REPORTS}

1 Colorimeters with Flow Through Cells. A critical assessment of 4 instruments. 1965. P. M. G. BROUGHTON and C. RILEY. 13s. 6d.

2 Colorimeters. A critical assessment of 5 commercial instruments. 1966. P. M. G. BROUGHTON, C. RILEY, J. G. H. COOK, P. G. SANDERS and H. BRAUNSBERG. 15s.

3 Automatic Dispensing Pipettes. An assessment of 35 commercial instruments. 1967. P. M. G. BROUGHTON, A. H. GOWENLOCK, G. M. WIDDOWSON and K. A. AHLQUIST. 10s.

\section{TECHNICAL BULLETINS}

3 Non-recording Spectrophotometers for the Visible and Ultraviolet Ranges. A comparative table of instruments available in Great Britain. May 1965. A. H. GOWENLOCK, P. C. NICHOLAS and J. H. WILKINSON. 1s. 6d.

4 Control Solutions for Clinical Biochemistry. June 1965. P. M. G. BROUGHTON and A. H. GOWENLOCK. 1s. $6 \mathrm{~d}$.
5 Recording Spectrophotometers. A comparative list of low-priced instruments readily available in Britain. July 1965. P. SEWELL. 2s. 6d.

6 A Guide to Automatic Pipettes. A list of more than 100 instruments compiled from manufacturers' literature. August 1965. P. M. G. BROUGHTON. 5s.

7 Variability Between AutoAnalyzer Modules. August 1965. B. E. NORTHAM. 1s. 6d.

8 Flame Photometers. A comparative list of 15 instruments readily available in Britain. June 1966. C. RILEY. 4s.

9 Determination of Urea by AutoAnalyzer. November 1966. RUTH M. HASLAM. 2s. 6d.

10 Filter Fluorimeters. A comparative list of 14 instruments. March 1967. HANNELORE BRAUNSBERG. 5s.

11 Determination of Serum Albumin by AutoAnalyzer using Bromocresol Green. October 1967. B. E. NORTHAM and G. M. WIDDOWSON. 2s. 6d. 